\title{
WHY CONFLICTS OCCUR IN ROADS AND TUNNELS PROJECTS IN NORWAY
}

\author{
Omar K. SABRI*, Ola LÆDRE, Amund BRULAND \\ Department of Civil and Environmental Engineering, Norwegian University of Science and Technology, \\ Trondheim, Norway
}

Received 19 September 2018; accepted 20 December 2018

\begin{abstract}
Conflicts within the Norwegian construction industry have reached unacceptable levels. The grievance of these disputes, whether it is the number of conflicts or the expense involved in these conflicts, is under discussion. This article examines the reasons for these conflicts in a comprehensive and inclusive manner. Twenty-five respondents with expertise and understanding of most conflicts in the Norwegian construction industry were interviewed. Results from a questionnaire sent to 1799 contractors have also been included in this study. Sixteen reasons for disputes were identified out of which four comprised the root causes. Tender specification and contract understanding came in first followed by "final settlement-payment related", corroborating previous findings. The third and fourth root causes of conflicts were "low priced contracts" and "changes in projects" respectively. Our findings point to design deficiencies and defective contract plans as significant causes of conflicts, confirming the view of construction experts. The third root cause of conflicts might explicate some aspects of the first and second major causes of disputes. It is also important to mention that though this is the general view, one can also see how every group involved in this study interpret major causes of conflicts. Our findings also point to "communication between clients and contractor", "carried out quantities" and "client restriction to time extension" as among the chief causes of conflicts, confirming the view of construction experts. Client understanding of contractors' anxiety and quest for sound contracting process are aspects that Norwegian clients are currently engaging in, for the sake of conflict reduction and prevention in future construction projects.
\end{abstract}

Keywords: disputes, construction, tenders, contracts, conflicts, infrastructure, feasibility, tunnels, roads.

\section{Introduction}

Disputes between contractors and clients in the construction sector are global problems that need to be addressed. The most recent publicly available report on global construction disputes pegged the value of disputes globally at US\$ 43.4 million in 2017, a significant increase from US\$ 32.5 million in 2016, with the average length of disputes spanning 14.8 months in 2017, an increase from 13.9 months in 2016 (ARCADIS, 2018). No nation is exempt from this problem, and Norway is no exception, prompting a call for a dialogue between stakeholders to combat the challenges arising from conflicts that have reached an unbearable status (Homleid, 2015a, 2015b).

The burden of the significantly high cost of these conflicts is borne by contractors as well as their clients. Though the value of global disputes has marginally reduced, the durations have markedly increased creating multiple effects for both parties and are likely to have a negative impact on the construction industry. The rising conflict levels within the Norwegian construction industry were highlighted by the Norwegian Public Roads Administration (NPRA) in 2014 and is reflected in Figure 1 clearly showing an upward shift in the level of disputes between the investigated time frames of 2008-2012 and 2013-2017, reaching unacceptable levels since 2013 (Hegerberg, 2016).

\section{Disputes in the construction industry}

Studies aimed at investigating the source, severity and impact of conflicts in the construction industry (Jaffar, Tharim, \& Shuib, 2011) focus on how conflicts that occur due to project delays and overheads incurred by interested parties, which is ultimately reflected in the quality of delivered work, inhibit the growth of the construction industry (Brockman, 2013). An evaluation of the origin

\footnotetext{
*Corresponding author. E-mail: omar.sabri@ntnu.no
} 


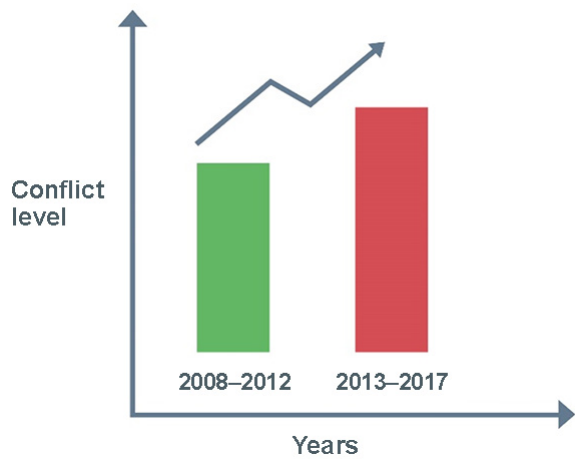

Figure 1. The level of conflicts in Norway from 2008-2017 (adapted with permission) (Hegerberg, 2016)

of conflicts globally in the construction industry is vital to adequately develop conclusions from the research methodologies employed (Min, Jang, Han, \& Kim, 2018). Jahren and Dammeier (1990) implemented an in-depth and detailed investigation into the primary reasons for the high number of disputes and revealed payment issues such as low-bidder system, change in assumed ground conditions, tender- and specification-related matters, and highlighted delays and lack of communication as among the primary causes of claims.

Semple, Hartman, and Jergeas (1994) specifically investigated cost and time overruns within the domain of construction claims and disputes in Canada and their findings are summarized in Figure 2. Among the factors were extreme weather conditions in reference to the cold weather in Canada and access to work site, a reason that is seldom considered when investigating the causes of disputes, and acceleration of work, which refers to a situation wherein clients attempt to compensate for delays by enforcing work speeding that enhances conflicts with the contractor. Increase in the scope of work is another reason for conflicts, irrespective of which party in the contract is responsible for the change. Whereas the contractor might attempt to change the scope of the work in order to derive

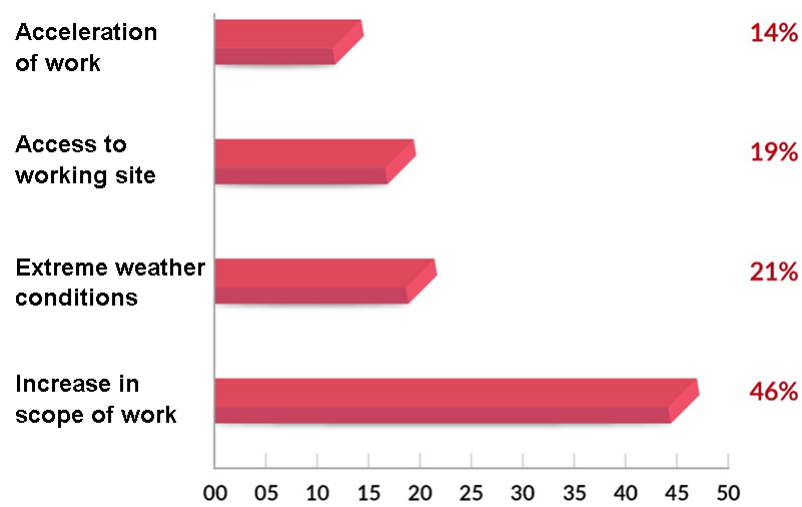

Figure 2. Investigating causes for construction claims and disputes (adapted from Semple et al., 1994)
Table 1. Common sources of construction claims and disputes (adapted from Kumaraswamy, 1997)

\begin{tabular}{|l|l|}
\hline \multicolumn{2}{|c|}{ Common sources of construction claims and disputes } \\
\hline \multirow{4}{*}{$\begin{array}{l}\text { Root causes } \\
\text { of claims }\end{array}$} & Unclear risk allocation \\
\cline { 2 - 3 } & Unrealistic time/cost/quality by client \\
\cline { 2 - 3 } & Adversarial industry culture \\
\cline { 2 - 3 } & Unrealistic tender pricing \\
\cline { 2 - 3 } & Inappropriate contract type \\
\cline { 2 - 3 } & Lack of competence of project participants \\
\cline { 2 - 3 } Proximate & Lack of professionalism of project participants \\
\cline { 2 - 3 } claims & Client lack of information or decisiveness \\
\cline { 2 - 3 } & Poor communication \\
\cline { 2 - 3 } & Vested interests \\
\cline { 2 - 3 } & Changes by client \\
\cline { 2 - 3 } & Slow client response \\
\cline { 2 - 3 } & Estimating errors \\
\cline { 2 - 3 } & Inadequate contract administration \\
\cline { 2 - 3 } & Inaccurate design information \\
\cline { 2 - 3 } & Incomplete tender information \\
\hline
\end{tabular}

more benefits, the client may attempt to do likewise due to abruptly emerging needs, as shown in Figure 2.

Most conflicts in the US construction industry fell under three categories (The Construction Industry Institute, 1995), which is a recurring theme in other countries as well. In the first, project conditions launched disagreements and ongoing revisions that eventually escalated into conflicts. In the second category, imperfect contracting process generated unrealistic expectations that eventually led to disputes. Lastly, personality and poor interpersonal and communication skills, as well as unethical behavior of the parties involved in projects generated conflicts (The Construction Industry Institute, 1995). Kumaraswamy (1997) addressed the main sources of conflicts in the construction industry by categorizing the causes of disputes into "root causes" and "proximate causes", the conclusions of which are presented in Table 1.

The highest ranked reason for conflicts often recurred in many other cases, and has been corroborated by other researchers (S. Mitkus \& T. Mitkus, 2014). Cheung and Pang (2013) performed a fuzzy analysis of the type and nature of disputes and classified them into three categories - contract incompleteness, task factor and people-related disputes. With reference to contract incompleteness, disputes commonly emerged in the risk allocation procedure, as it was unfair to shift risks to the contractor, as is the common practice of some clients. Task factor for dispute claims include dichotomies in the interpretation of contracts by contractors, which eventually escalated into conflicts. People-related disputes refer to human factors including emotions and/or behavioral issues. 
Table 2. Common causes of disputes by categories (adapted from E. Cakmak \& P. I. Cakmak, 2014)

\begin{tabular}{|c|c|}
\hline $\begin{array}{l}\text { Category of } \\
\text { disputes }\end{array}$ & Causes of disputes \\
\hline \multirow[t]{6}{*}{ Owner related } & Variations initiated by the owner \\
\hline & Change of scope \\
\hline & Late giving of possession \\
\hline & Acceleration \\
\hline & Unrealistic expectations \\
\hline & Payment delays \\
\hline \multirow{6}{*}{$\begin{array}{l}\text { Contractor } \\
\text { related }\end{array}$} & Delays in work progress \\
\hline & Time extensions \\
\hline & Financial failure of the contractor \\
\hline & Technical inadequacy of the contractor \\
\hline & Tendering \\
\hline & Quality of work \\
\hline \multirow[t]{4}{*}{ Design related } & Design errors \\
\hline & Inadequate/Incomplete specification \\
\hline & Quality of design \\
\hline & Availability of information \\
\hline \multirow{4}{*}{$\begin{array}{l}\text { Contract } \\
\text { related }\end{array}$} & Ambiguities in contract documents \\
\hline & $\begin{array}{l}\text { Different interpretations of the contract } \\
\text { provisions }\end{array}$ \\
\hline & Risk allocation \\
\hline & Other contractual problems \\
\hline \multirow{3}{*}{$\begin{array}{l}\text { Human } \\
\text { behavior } \\
\text { related }\end{array}$} & Adversarial / controversial culture \\
\hline & Lack of communication \\
\hline & Lack of team spirit \\
\hline
\end{tabular}

E. Cakmak and P. I. Cakmak (2014) analyzed dispute claims in 14 countries and categorized the causes of dispute claims based on the component of the conflicts (Table 2).

Categories, such as "owner-related" and "contractorrelated" provide a thorough view of any specific conflict situation. Mehany \& Grigg (2014) performed a regression analysis to investigate the causes of claims in roads and bridges projects in Colorado and attributed "delays" to be the main cause of claims in Colorado. Another study

Table 3. Common causes of conflicts in construction projects - compared study (adapted from Elmagdobi, Čulić, Beljaković, Milajić, \& Pejičić, 2016)

\begin{tabular}{|c|l|}
\hline Rank & \multicolumn{1}{|c|}{ Causes } \\
\hline 1 & Delays in payment \\
\hline 2 & Contract related \\
\hline 3 & Evaluation and communication \\
\hline 4 & Design error \\
\hline 5 & Unclear specification \\
\hline
\end{tabular}

Table 4. Dispute causes in 2016 - an overall conclusion (adapted from ARCADIS, 2017)

\begin{tabular}{|c|l|c|}
\hline $\begin{array}{c}2016 \\
\text { Rank }\end{array}$ & \multicolumn{1}{|c|}{ Dispute Cause } & $\begin{array}{c}2015 \\
\text { Rank }\end{array}$ \\
\hline 1 & Failure to properly administer the contract & 1 \\
\hline 2 & $\begin{array}{l}\text { Poorly drafted or incomplete and } \\
\text { unsubstantiated claims }\end{array}$ & 2 \\
\hline 3 & $\begin{array}{l}\text { Employer/Contractor/Subcontractor failing } \\
\text { to understand and/comply with contractual } \\
\text { obligation }\end{array}$ & 5 \\
\hline 4 & $\begin{array}{l}\text { Errors and/or omissions in the contract } \\
\text { document }\end{array}$ & 3 \\
\hline 5 & $\begin{array}{l}\text { Incomplete design information or employer } \\
\text { requirements (for Design-Build and Design } \\
\text { \& Construction) }\end{array}$ & 4 \\
\hline
\end{tabular}

comparing the common causes of conflicts in construction projects in Libya and Serbia arrived at interesting results, described in Table 3.

Table 4 shows the causes of disputes around the world in 2016, and how these causes have changed since 2015. The five major causes of disputes vary from one country to another. This review of literature clearly shows variation in the causes of disputes across the globe and one can infer that the reasons for dispute and conflicts in a specific country may not apply to another.

With emphasis on Norway, several sources of conflicts including deficient or insufficient design, uncertain management and personal chemistry were previously identified (Lædre, 2015). A group of Norwegian engineers and experts published a report on the BAROK (Norwegian acronym representing: Bygg og Anlegg - Rekruttering og Kompetanseutvikling) project, which was responsible for three major areas of the industry - education for technical staff and skilled workers, building and construction industry reputation, and trends in social development (BAROK, 1999). On the contractors' side, major participants included NCC, Selmer and Veidekke who were major stakeholders in the Norwegian construction industry. The NPRA, STATSbygg and Norsk Hydro Technology and Development represented the clients. STATSbygg is the main advisor to the Norwegian government on property management and property development, whereas Norsk Hydro is a Norwegian aluminum and renewable energy company with almost $50 \%$ of its shares owned by the Norwegian government, underscoring the fact that the BAROK report is not solely focused on construction projects. Despite its relative antiquity, data provided by the BAROK project are paramount to understanding disputes in the construction sector in Norway. The findings of the BAROK project are presented in Figure 3, which shows the causes of conflicts in the construction sector in Norway.

Contract misunderstanding combined with weak interpretation of contracts and tenders were identified as the root causes for conflicts in Norway (Table 5). 


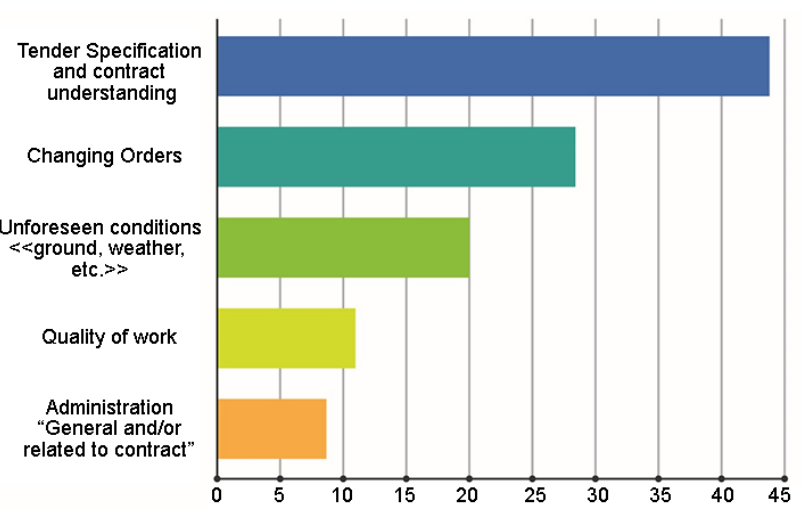

Figure 3. Root causes of conflicts in the Norwegian building and construction sector (reproduced with permission)

(BAROK, 1999)

Table 5. Proximate causes of conflicts in the Norwegian building and construction (reproduced with permission) (BAROK, 1999)

\begin{tabular}{|l|c|}
\hline \multicolumn{1}{|c|}{ Reason of dispute - Proximate causes } & Frequency \\
\hline Incomplete tender information & 20 \\
\hline Tight schedule & 13 \\
\hline $\begin{array}{l}\text { Lack of expertise, experience and cooperative } \\
\text { ability of the parties' representatives }\end{array}$ & 11 \\
\hline Unilateral protection of own interests & 10 \\
\hline Contract deviation & 8 \\
\hline Lack of profit & 7 \\
\hline Tender mechanism (Selection of lowest bidder) & 3 \\
\hline Unclear risk allocation in the contract & 3 \\
\hline
\end{tabular}

Further, changes in work or orders along with deficiencies in the quality of work delivered also contributed to conflicts, with the latter being identified as a critical cause in the present study. Contractual disputes may occur when a contractor attempts to change the contract for some reason but might not elicit a positive reaction from the public owner, which may result in denial of payments to the contractor. Similarly, contractors' liquidity problems can have dire consequences and there are calls for project delivery system employed in the Norwegian construction industry to be more dynamic (Engesæth, 2015).

An investigation into the recent increase in the number of dispute claims in the Norwegian construction industry has attributed this rise to four main reasons. The primary cause for conflicts is the lack of experience among contract owners, which might be linked to a shortage in certain types of projects, due to insufficient funding for risk as some projects can be evaluated as too optimistic in terms of cost estimates. Pressure from the public to resist from alterations and modifications to the project, and finally strict profit requirements due to competition in the heavy construction sector, in which case contractors try to seek additional profits through the court system (Grøv, 2014) (Figure 4).

Based on information gathered from more than 60 Norwegian roads projects, the Norwegian Directorate of Public Roads identified major causes of conflicts (Figure 5). Lack of documentation was identified as an important cause for conflicts and the need for contractors to be better organized was recommended. It was also recognized that the ground conditions were not significant reasons for dispute with regards to participation. Also, inadequate preparatory work by the public owner can be at fault and better preparations during the tender design and planning was recommended (Henning, 2015).

A study conducted by a major construction firm in Norway corroborated the above mentioned known causes and highlighted other interesting causes for disputes (Haukedalen, 2015). An imbalance in contract and specifications, in addition to the lack of qualified and skilled professionals for effectively interpreting contracts, insufficient design accuracy and liquidity by the contractor, who becomes vulnerable to payment delay, and absence of mandate by project level staffers as small disagreements between parties could escalate, were identified as causes for disputes. Since construction contracts in Norway have become more complex, it is therefore valuable for parties involved to develop and infuse more experience into existing staff. Changing orders are always among the causes for disputes in Norway and in other parts of the world. It was also noted that changes ordered by owners led to

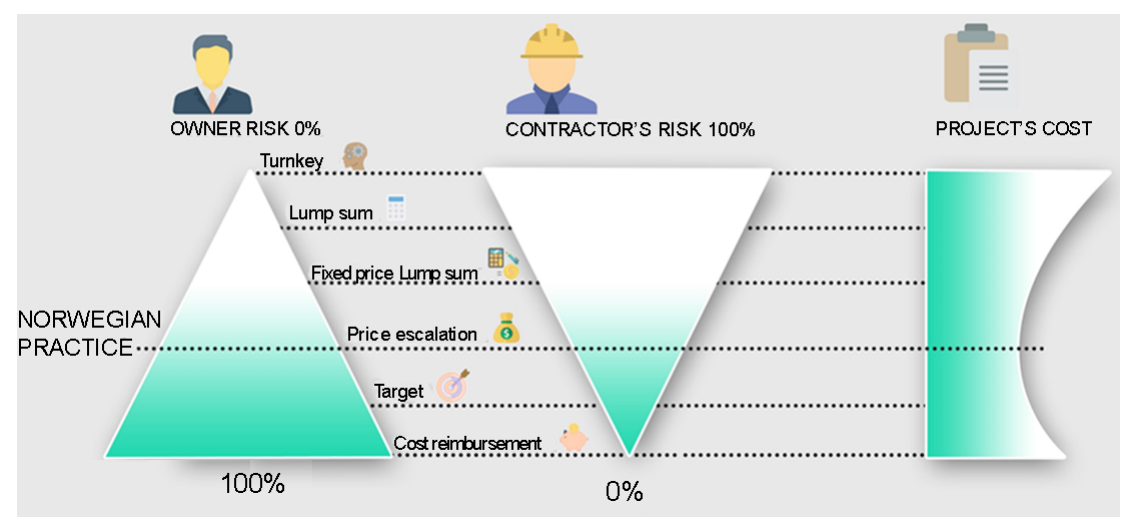

Figure 4. Risk allocation principles used in Norwegian tunnelling contracts (Grøv, 2014) 


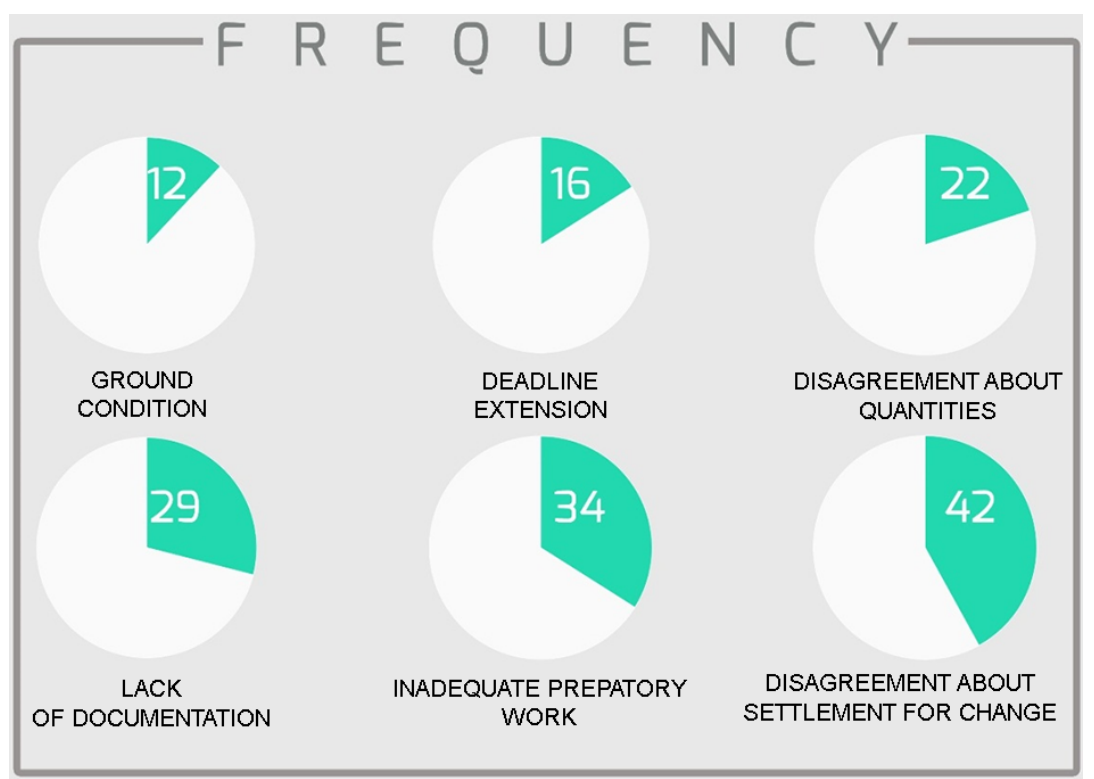

Figure 5. Causes of conflicts in the Norwegian construction industry (reproduced with permission) (Henning, 2015)

large final settlement requirements. Another issue that is currently tackled by the Norwegian authorities is the lowpriced project delivery mechanism that has been implemented since 2015. Finally, the study implied that there is little use of "binding" dispute resolution mechanisms (Haukedalen, 2015).

Several years of experience in conflicts in the construction industry resulted in an expert opinion that risk distribution between contractor and owner was a crucial cause for conflicts (Kobbe, 2016), despite the reality that the Norwegian contract system tends to put the burden of the risk on the public owner. It was also observed that preparations made by the public owner were usually insufficient and there was a need for improvement. Similarly, the mandate or hesitation to take action observed in many projects commonly resulted in deep misunderstandings and disagreements that stall the project.

Surprises in ground conditions can generate incongruity and disharmony between clients and contractors, if the contract system used is not qualified to address these issues. It must, however, be noted that this issue is properly addressed in the Norwegian Contract System in its so-called "sharing of risk concept" (Kleivan, 1989), which mandates that the client retains the risk resulting from the pervading geological conditions surrounding the project, while the contractor assumes the risk related to delivering good quality of work. This is commonly employed in unit price contracts combined with design-bid-build project delivery framework (Grøv, 2014).

According to Kobbe (2016), pricing contracts and the selection of lower bidders were highlighted as the reasons for conflicts wherein the contractor, in order to win the contract, lowers costs and seeks loopholes in the contract, thereby creating unpleasant "surprises" for the owner resulting in disputes. Tactical pricing therefore becomes a source of disputes. The core findings made by Kobbe
(2016) will be correlated to the results obtained in the present study.

Since 2015, the Norwegian University of Science and Technology has focused its research efforts towards investigating conflicts in the construction industry. The current study is a renewed examination of conflicts in construction projects in Norway with the aim of identifying root and proximate causes of conflicts. To achieve this objective, in this study we investigated root and proximate causes of conflicts and questioned whether contract related causes, ground conditions, personal characteristics, lack of liquidity and delays were the primary causes of conflicts in construction projects in Norway. Since access to data from the Norwegian Association of Heavy Equipment Contractors (MEF) survey (Gunnes, 2018) was made available to us, our analysis included a comparison to the MEF findings. Our study yielded valuable results that may contribute immensely to a better understanding of the nature and causes of conflicts and identify ways and means to minimize these conflicts.

\section{Methodology}

Due to the lack of an existing database of conflict cases that can be utilized in this research, a qualitative method (Barriball \& While, 1994; Attride-Stirling, 2001) was devised for this study. Twenty-five semi-structured interviews were conducted with experts from the Norwegian construction industry who enjoyed deep understanding of the realities and background of most conflicts. The respondents in these interviews included individuals relevant to disputes in the construction industry including contractors, consultants, clients, lawyers and academics.

The list of selected respondents factored in the importance of this research for the Norwegian construction industry and was based on the recommendation of various 
researchers who had investigated similar or related topics (Tabish \& Jha, 2018). As representatives of the contractor category, several construction companies and their CEOs were selected as respondents. In the public client category, it was important to include representatives of Bane NOR and NPRA as they owed large sums of money to contractors for finished or unfinished projects. Lawyers are known to vary in their opinions regarding the appropriate approach to handle construction disputes - whether to undertake the traditional litigation or attempt Alternative Dispute Resolution (ADR) methods (Pavalon, 1987). Lawyers were chosen according to their experience and involvement in disputes in the construction industry. It was also deemed useful to engage consultants in this process to contemplate their opinions on the state of the current Norwegian construction industry.

The present research study spanned more than one year from start to finish and involved 25 respondents carefully selected to include most of the stakeholders and parties involved in construction disputes. The final list of respondents included five contractors, seven clients including public clients such as the NPRA and Norwegian National Rail Administration. Added to that, five lawyers with extensive experience in handling disputes, three academics from the Norwegian University of Science and Technology who have been involved in many arbitration and/or court cases related to roads and tunnels projects as neutrals and/or as arbitrators, and five consultants (Jahren \& Dammeier, 1990).

The interview questions were open-ended initially, which allowed 14 respondents, who had not been provided with a defined set of multiple-choice answers to each question, to decide on the focus of their answers themselves based on their individual experience. The analysis of answers from these respondents allowed the development of a list of answers to each question (Attride-Stirling, 2001). This list was not shown to the subsequent 11 respondents but was used as a guide for the interviewers. To ensure optimal objectivity, all responses were registered regardless of their oddity or peculiarity and a final record of answers registered for this study was incorporated into the manuscript.

Each respondent was asked 21 questions that were tailored to achieve the goal of highlighting and evaluating the causes of conflicts in the construction projects in Norway, including whether personal characteristics and types of contracts were factors. Responses were tabulated for use in the present study or for future purposes if they were irrelevant to the present research question (Barriball \& While, 1994).

In addition, in response to feedback from the construction industry, the MEF in early 2018, surveyed the reasons for payments blocked by the NPRA (Gunnes, 2018) through questionnaires directed to 1799 of its members. The results of this survey were made available to us and were used to draw comparisons to the findings made in this study.

\section{Descriptive analysis}

Responses from the interviews were analyzed by coding the responses using MS Excel spreadsheet as described earlier (Driscoll, Appiah-Yeboah, Salib, \& Rupert, 2007) with the aim of performing statistical data analysis using SPSS and MS Excel. Frequency indicated the number of times a particular reason was repeated by the respondents. Dispute reasons with higher frequencies had greater leverage. To determine whether variables identified from the responses were significant enough to lead to conflict, the statistical significance of these variables was determined using ANOVA for all independent variables, which comprised a dataset labelled 1 to 18 .

\section{Results and discussion}

This study attempted to investigate the causes of conflicts in the Norwegian construction industry through semi-structured interviews of various stakeholders. The respondents in the interviews relied on their experience to provide answer questions, which were curated to arrive at the most usable and logical text. The average scores for all the respondents varied between 2.0 and 3.5, which im-

Table 6. Summary statistics for the 25 respondents

\begin{tabular}{|c|c|c|c|c|}
\hline \multicolumn{5}{|c|}{ Summary } \\
\hline Respondents & Count & Sum & Average & Variance \\
\hline 1 & 6 & 15 & 2.5 & 1.9 \\
\hline 2 & 6 & 17 & 2.833333 & 1.366667 \\
\hline 3 & 6 & 16 & 2.6666667 & 0.666667 \\
\hline 4 & 6 & 19 & 3.166667 & 0.566667 \\
\hline 5 & 6 & 16 & 2.666667 & 0.666667 \\
\hline 6 & 6 & 17 & 2.833333 & 0.966667 \\
\hline 7 & 6 & 15 & 2.5 & 1.1 \\
\hline 8 & 6 & 14 & 2.333333 & 1.466667 \\
\hline 9 & 6 & 18 & 3 & 0.8 \\
\hline 10 & 6 & 17 & 2.833333 & 0.966667 \\
\hline 11 & 6 & 17 & 2.833333 & 0.566667 \\
\hline 12 & 6 & 15 & 2.5 & 1.9 \\
\hline 13 & 6 & 12 & 2 & 0.4 \\
\hline 14 & 6 & 15 & 2.5 & 1.9 \\
\hline 15 & 6 & 13 & 2.166667 & 1.366667 \\
\hline 16 & 6 & 16 & 2.6666667 & 1.466667 \\
\hline 17 & 6 & 13 & 2.166667 & 1.366667 \\
\hline 18 & 6 & 19 & 3.166667 & 0.966667 \\
\hline 19 & 6 & 14 & 2.333333 & 0.666667 \\
\hline 20 & 6 & 17 & 2.833333 & 1.366667 \\
\hline 21 & 6 & 18 & 3 & 0.4 \\
\hline 22 & 6 & 13 & 2.166667 & 0.566667 \\
\hline 23 & 6 & 19 & 3.166667 & 0.566667 \\
\hline 24 & 6 & 20 & 3.333333 & 1.066667 \\
\hline
\end{tabular}


Table 7. Results of the ANOVA test for questions excluding graded question

\begin{tabular}{|l|c|c|c|c|c|c|}
\hline \multicolumn{7}{|c|}{ ANOVA } \\
\hline Source of Variation & SS & $d f$ & $M S$ & $F$ & P-value & $F_{\text {crit }}$ \\
\hline Between Groups & 18.49306 & 23 & 0.804046 & 0.770856 & 0.760557 & 1.619655 \\
\hline Groups & 125.1667 & 120 & 1.043056 & & & \\
\hline Total & 143.6597 & 143 & & & & \\
\hline
\end{tabular}

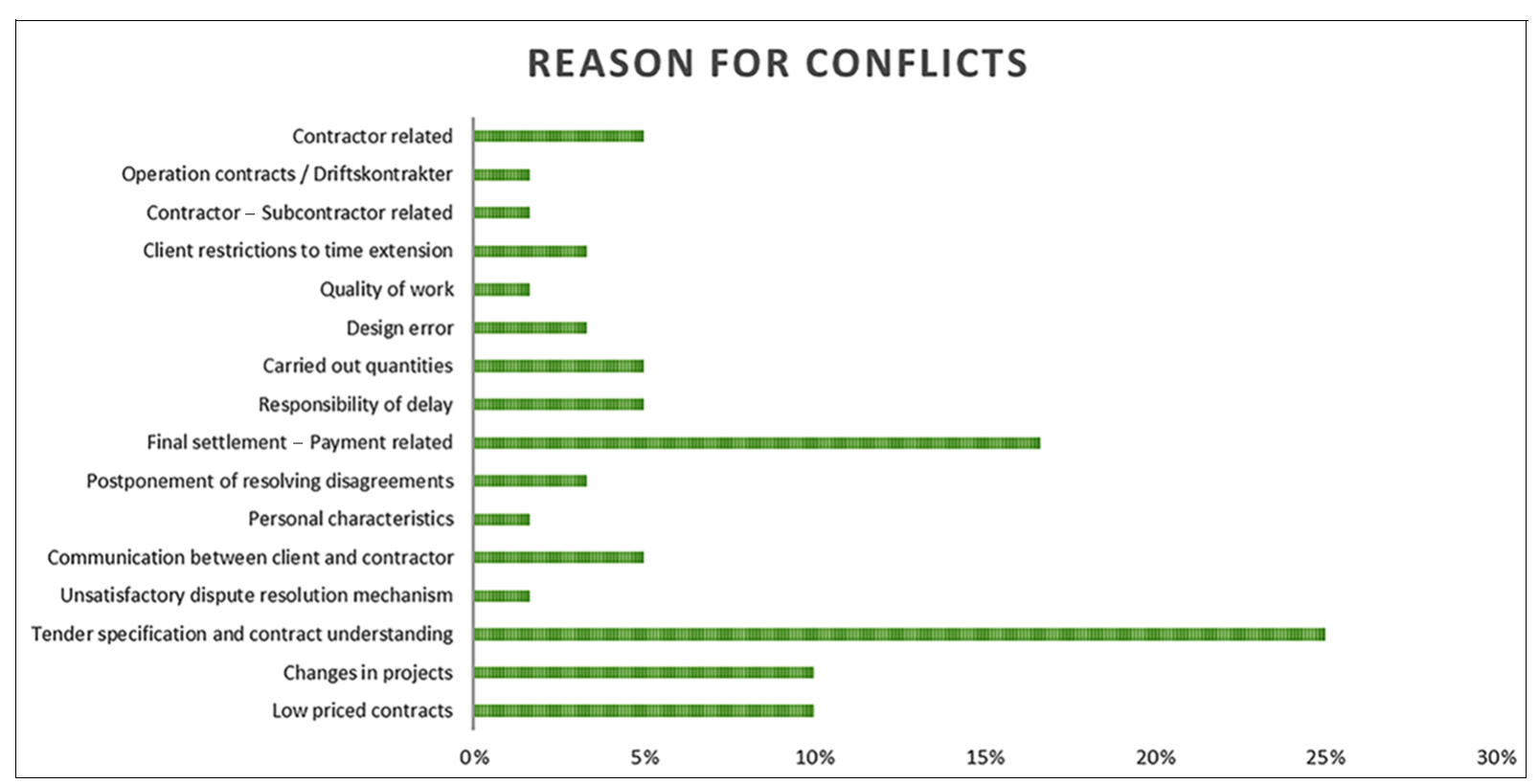

Figure 6. Causes of conflicts in roads and tunnels projects in Norway

plied that the score for most of the causes of conflicts fell below 3.5 (Table 6).

Between group significance for questions excluding the graded Question 22 was determined by ANOVA $(\mathrm{p}=0.77)$ (Table 7$)$ indicating no significance, likely due to the small sample size.

As shown in Figure 6, 16 reasons for disputes in the construction industry in Norway were identified, out of which four (tender specification and contract understanding, final settlement-payment related, low priced contracts, and changes in project) recurred more frequently than the others. In the jargon of Kumaraswamy (1997), these four most frequently cited reasons were "root causes", whereas the remaining were "proximate causes".
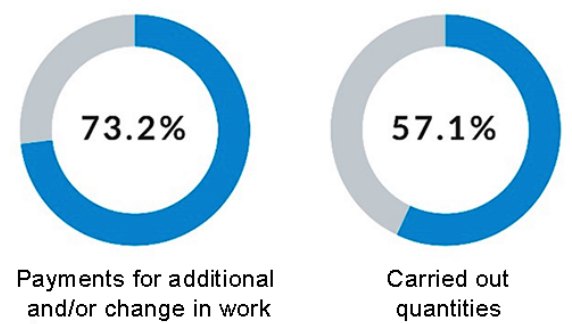

Among the root causes of conflicts identified in the present study, "tender specification and contract understanding" ranked first. This indicated that specifications with loopholes have been exploited by contractors to benefit unequally from the contract and was deemed the most significant cause of conflict identified in this study. It must be noted that if contractors were knowledgeable enough to find a ground for misunderstanding, then it was unnecessary to find loopholes in the contract.

"Final settlement - payment related" reason came in second rank and was obviously linked to changes in scope of work, which resulted in misinterpretation and exaggeration of the work performed. Internationally, this cause is regarded in research publications as "payment related"

Figure 7. Causes for blocking payments (adapted with permission) (Gunnes, 2018) 


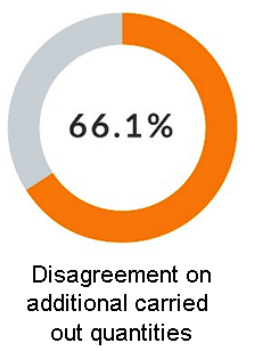

quantities

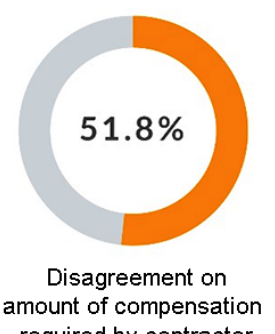

required by contractor

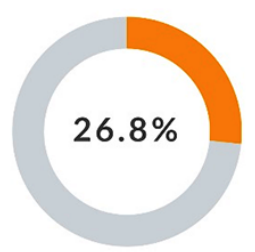

Lack or insufficient documentation

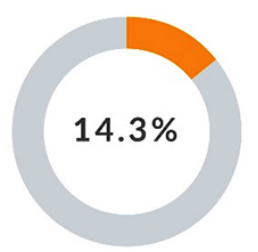

Other

Figure 8. Owner explanation for withholding payments (adapted with permission) (Gunnes, 2018)

causes (E. Cakmak \& P. I. Cakmak, 2014). A comprehensive analysis of responses from 700 members of which $37.6 \%$ had NPRA as their clients, found that among the respondents, "final settlement - payment related" issue was the root cause of disputes in Norway (Gunnes, 2018) (Figures 7 and 8).

"Changes in project" and "low priced contracts" were assigned third and fourth ranks, with a very small margin between the two categories. Change in work is a crucial basis for conflicts globally and can be linked to the difficulties that contractors experience in obtaining projects with stiff competition for roads and tunnels projects in Norway. In order to survive in the highly competitive market, some contractors are willing to lower their bid to a level that the contract is no more profitable, in the hopes that a change in

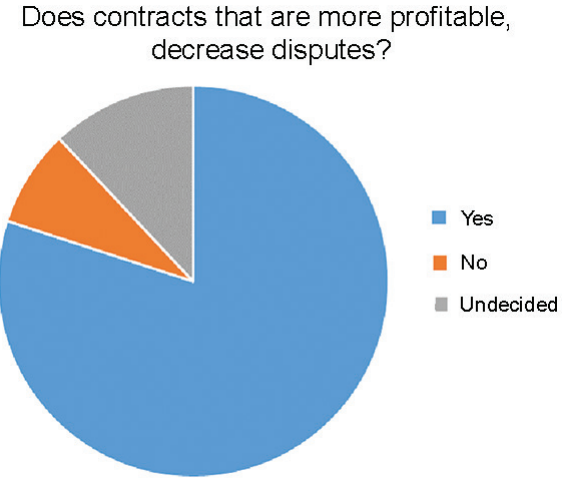

Figure 9. The effect of contract profitability on disputes

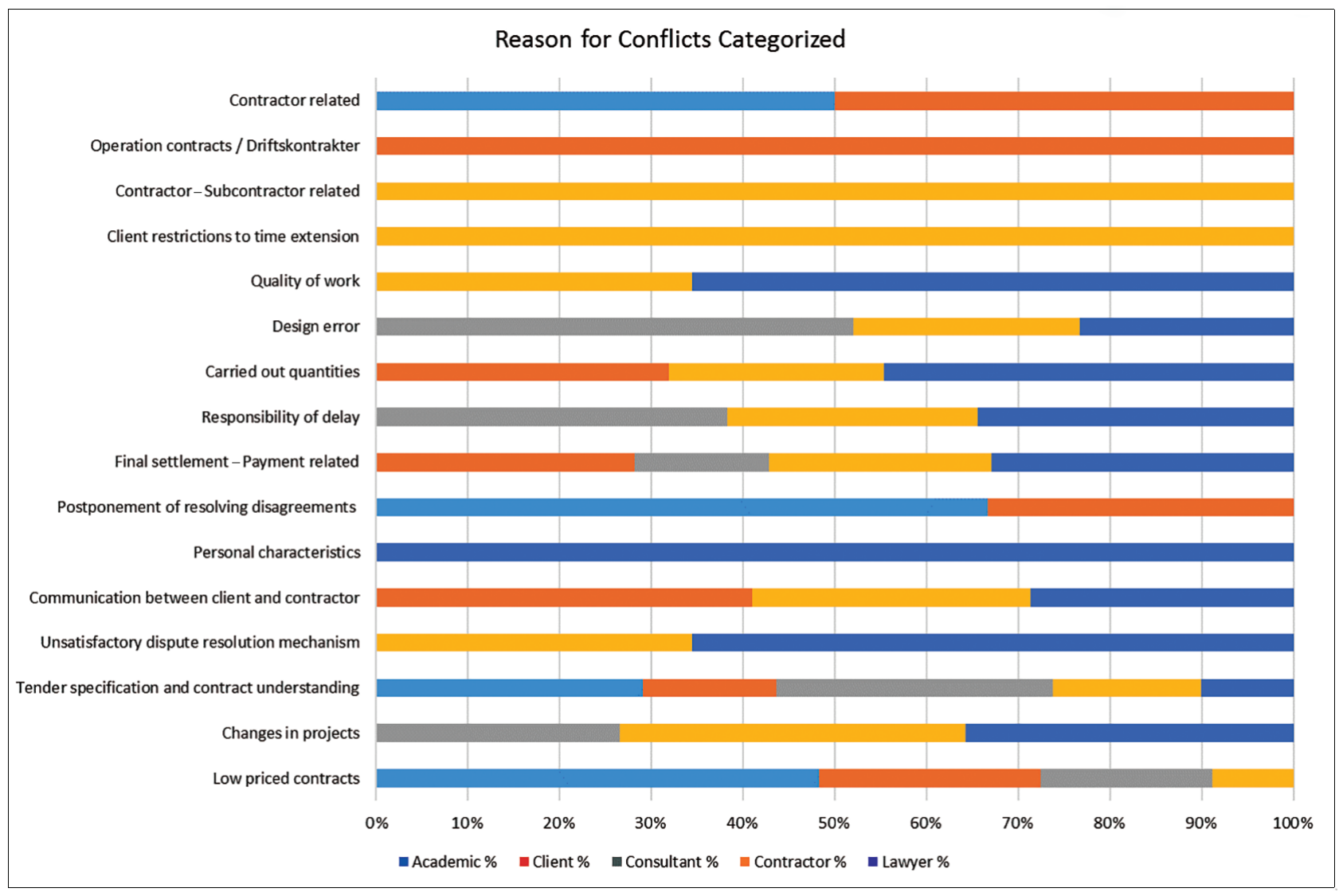

Figure 10. Reasons for conflicts in roads and tunnels projects in Norway 
order would provide a profitable remedy (Jahren \& Dammeier, 1990). "Low priced contracts", the fourth ranked root cause and among the major causes of conflicts in this study, was a separate question posed to the respondents. As shown in Figure 9, most respondents pointed out that the profitability of contracts reduced its susceptibility to conflicts in the short and long run.

In order to identify the most compelling reason for conflicts based on the experience and knowledge of the respondents, a categorized list of the causes of disputes was made based on the five groups of conflicts considered in this study and is shown in Figure 10. Among the highly ranked proximate dispute causes were "contractor-related" reasons, "carried out quantities" and "responsibility for delays", with "communication between client and contractor" ranked the lowest. Communication is decisive in any healthy and effective construction project as ineffective communication can create significant challenges.

The most significant causes of conflicts, if not all, have been mentioned by most respondents. Our study separated root causes from proximate causes of conflicts in Norway, corroborating results obtained from previous studies (Mehany \& Grigg, 2014). Differences in prioritization and categorization were also noted; some groups highlighted certain reasons that others did not mention or did not consider as important contributors to conflicts. In particular, only clients cited "operation contract", whereas "contractor - subcontractor related" and "client restrictions to time extension" were mentioned only by contractors, comparable to findings made previously (Cheung \& Pang, 2013). Similarly, "personal characteristics" was highlighted only by lawyers, despite personal characteristics being a significant contributor to conflicts that was emphasized in a separate question in the interview and subsequently in the rated question.

The relationship between contract type and conflicts was measured in this study since some contractors argue that contract type is significantly related to conflict level observed in the Norwegian market (Aage, 2018). These contractors hoped that unit price contracts were developed or transformed into other types of contracts as projects became increasingly elaborate and comprehensive. As shown in Figure 11, a majority of the respondents agreed that no specific contract type contributed to the dispute

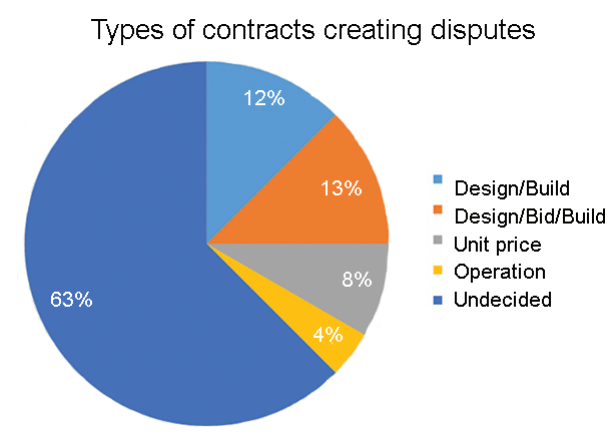

Figure 11. Types of contracts creating disputes in Norway

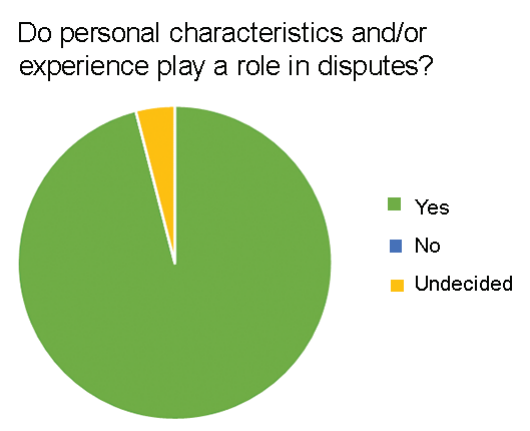

Figure 12. The effect of personal characteristics on disputes

process more than others, despite minor variations in their responses.

Others including Thompson, Vorster, and Groton (2001) and Henning (2015) have investigated various types of contracts with the aim of minimizing disputes in the construction industry. However, an in-depth evaluation of this topic is beyond the scope of this article as a thorough and comprehensive study focused solely on delivery methods and contract types that have undergone a measurable degree of disagreement is needed to address this issue.

In evaluating the contribution of personal characteristics as essential for minimizing disagreements, it was observed that the vast majority of respondents (Figure 12) agreed that it was crucial for the parties to develop a personal rapport necessary to curtail any misunderstanding that might occur during the project, in agreement with previous findings (Engesæth, 2015).

Prior to the interviews, certain key players, especially contractors in heavy construction projects, noted that they considered foreign companies as partial contributors to the problem, as contracts were no longer very profitable due to the fierce competition ignited by opening the Norwegian market to other European and international entrepreneurs. Therefore, the respondents were questioned

Are foreign companies' part of the problem?

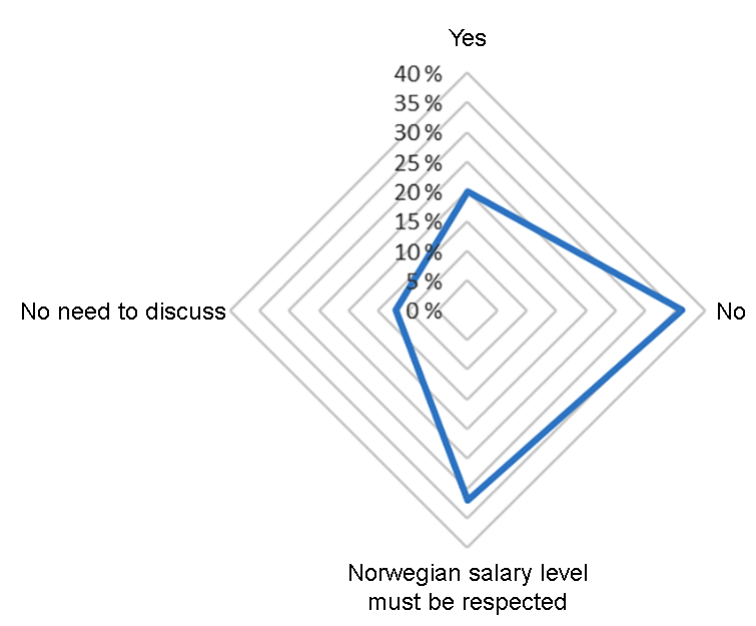

Figure 13. The contribution of foreign companies to conflicts in Norway 
Table 8. Results of ANOVA test for question 22 (Graded)

\begin{tabular}{|l|c|c|c|c|c|c|}
\hline \multicolumn{7}{|c|}{ ANOVA } \\
\hline Source of Variation & $S S$ & $D f$ & $M S$ & $F$ & $P$-value & $F_{\text {crit }}$ \\
\hline Between Groups & 22.44 & 40 & 0.704046 & 1.755693 & 0.006056 & 2.000005 \\
\hline Groups & 100.9923 & 122 & 0.943056 & & & \\
\hline Total & 146.22 & 162 & & & & \\
\hline
\end{tabular}

regarding the entry of foreign players to the Norwegian market and the results of this inquiry are shown in Figure 13. Most respondents confirmed that indeed foreign competition contributed to increasing conflicts and an equal number opined that Norwegian salary levels must be respected.

Each respondent was questioned on the severity of six possible causes of disputes by assigning grades based on their understanding of the issue in question 22 (Figure 14) of the questionnaire. The grading was on a scale of $1-4$, one being the lowest and four being the highest possibility (Barriball \& While, 1994). All the causes were significant contributors of conflicts in the Norwegian construction industry $(\mathrm{p}=0.006)$ (Table 8$)$ and were therefore more significant compared to other causes in generating conflicts.

Rated questions related to contractor's lack of liquidity and changes in contracts based on Norwegian standards were graded low, whereas "ground conditions", "personal characteristics", "contract related" and "delays" questions were rated high. Mehany and Grigg (2014) previously demonstrated that delays were more challenging issues for some markets than others. Delays can be a basis for conflicts, where "changes to the order" by the contractor causing the delay was not fully supported by the client, or the client considers that the changing order should not have caused a delay. Thus, it could be deduced that controlling for contractor's lack of liquidity, delays, ground conditions, personal characteristics, contract-related issues and changes in Norwegian standards may be sufficient to minimize conflicts in the Norwegian construction industry (Figure 14).

Entrepreneurs are generally inclined towards project delivery, as it permits all the parties to get involved in the project as early as possible. This would provide contractors

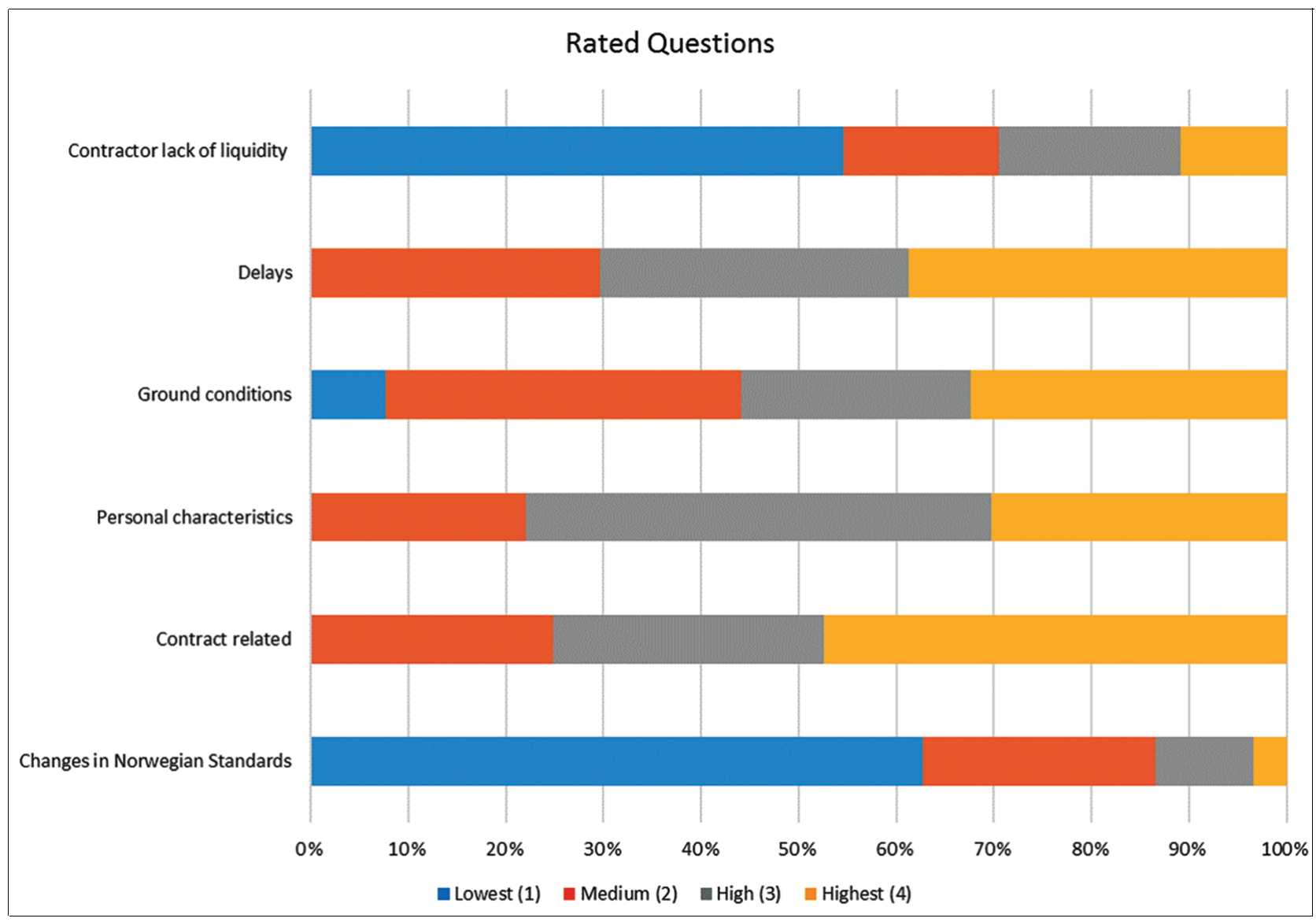

Figure 14. Rated questions - rates were given from 1 to 4 
with the necessary understanding of the contract, and aid in the development of suitable technical solutions, along with good communication skills that may be a valuable by-product of the design/build contracts (Homleid, 2016) (Figure 11). It must be noted that large scale contracts pose significant difficulties for entrepreneurs to meet deadlines, and such contractors rely on the understanding and cooperation of the public owners involved. Conflicts also arise when negotiations fail at the start of the project, which begets larger issues that may not be solved through reconciliation of the involved parties.

Our results indicate that conflict control can be achieved through effective negotiation and clarification of construction contracts, wherein the project manager and the contractor reach mutual agreements to resolve disputes that may arise before considering alternative measures. As well, proper documentation and improved communication can mitigate conflicts since it is recognized that incorrectly organized contract documents increase errors that will eventually result in conflicts during project execution. Therefore, open discussions between interested parties involved at every stage of the project can ameliorate conflicts.

Our findings point to design deficiencies and defective contract plans as significant causes of conflicts, corroborating the view of construction experts (Jaffar et al., 2011). Deployment of adequately prepared and experienced staff with a broad knowledge of the workings of construction projects, implementing proper risk management, and sustaining commitment to clients' needs and requirements, are essential to avoid conflicts during the project execution phase. A proper follow-up on the causes of disagreements, ensuring adequate understanding and the ability to settle disputes out of court in construction contracts are vital in reducing or eliminating disputes. Most importantly, contractors should always be driven by realistic and sensible ambitions.

Conflict resolution methods vary significantly in terms of the cost involved. In this case, negotiation can be viewed as the most effective and reliable approach to resolve a conflict, followed by mediation, adjudication, arbitration and finally litigation, which is the most expensive method. Constant communication ensures conflict resolution through negotiation, and substantially improves chances of conflict resolution at an early stage.

In the current study, almost all the relevant reports, including lectures, reports and seminars based on investigations by NPRA, large law firms and entrepreneurs that have been published in Norway within the past twenty years were reviewed, along with international publications that have examined disputes in the construction industry. The study was limited to construction projects encompassing roads, highways and tunnels, for which the NPRA is usually the client; building and housing projects, were excluded from this study. Conflicts investigated were limited to those between private enterprises and public owners, such as the NPR or the Bane NOR, as the contractors' requirements from these state-owned companies have skyrocketed within the last few years. A significant limitation of this study is the lack of analysis of disputes between contractors and sub-contractors since published literature indicates that $57.6 \%$ of the contractors and sub-contractors had experienced conflicts in the past year (Gunnes, 2018). This could be a subject of future investigation.

\section{Conclusions}

This study was designed to take the pulse of the current construction industry in Norway, focusing on the increasing number of conflicts and disputes (Hegerberg, 2016). Tender specification and contract understanding, final settlement-payment related, low priced contracts, and changes in project) recurred more frequently than the others and were, in this study, identified as "root causes" of conflicts as defined by Kumaraswamy (1997). This indicated that specifications with loopholes have been exploited by contractors to benefit unequally from the contract and was deemed the most significant cause of conflict identified in this study. Tender specifications and contract understanding remain the most potential causes of conflicts in Norway, followed by disagreements on final settlement usually issued by the public owner, whether it is the NPRA or the Bane NOR. Evidently, a clear dispute management pattern must be put in place to parallel investments in Norwegian infrastructure, which has increased rapidly.

It may be recommended that contracts with greater feasibility would minimize the need for entrepreneurs to exploit loopholes in contracts, with the aim of increasing their profit or to attain a level of profitability that would improve the performance record of the construction contractor (Groven, Hafskjær, \& Ferstad, 2017). Further, the NPRA may be considered as an exceptionally flexible public organization genuinely interested in the financial and operational sustainability of its contractors, whilst challenging them to aim for the delivery of optimal quality of work. Contractors are therefore encouraged to strive to meet the standards and expectations of the NPRA.

Our findings differ marginally, but not dramatically, from the findings obtained nearly a decade ago (BAROK, 1999). However, our findings corroborate those made previously by Kumaraswamy (1997), which outlined the foundational understanding of conflicts. It must be noted, however, that the Norwegian market is unique and distinct from other markets, and therefore the sources of conflicts vary slightly from one region to another.

The findings of this study are of substantial importance to stakeholders and concerned entities in infrastructure and construction projects in Norway, and particularly entrepreneurs, who are the backbone of infrastructure projects in Norway. 


\section{Acknowledgements}

We would like to thank all who assisted in this project. In particular, Norwegian Public Roads Administration (Statens vegvesen), Norwegian National Rail Administration (Bane NOR) and Norwegian Association of Heavy Equipment Contractors (MEF), who have been a great resource for information and data. They responded to our queries, shared their data, and granted access to their extensive database of entrepreneurs to find answers related to conflicts in the construction industry. We also extend our immense gratitude to private contractor firms, consultant firms, lawyers and academics who have not spared any effort to let this work come to light.

\section{Funding}

Norwegian University of Science and Technology funded this research.

\section{Author contributions}

Author one reviewed the theory nationally from Norway and internationally, gathered information and data from Norway through interviews and data collection survey in coordination with the Society of Construction Machinery, analyzed data and drew conclusions. The second and third author supervised author one, assisted in literature search and interviews, and reviewed the data.

\section{Disclosure statement}

No conflict of interest is involved in this article nor any competing financial, professional, or personal interests from other parties.

\section{References}

Aage, F. (2018). Albert and rocks. Byggeindustrien, 9, 52-53. ARCADIS. (2017). Global construction disputes report 2017: Avoiding the same pitfalls. ARCADIS Publications.

ARCADIS. (2018). Global construction disputes report 2018: Does the construction industry learn from its mistakes. ARCADIS Publications.

Attride-Stirling, J. (2001). Thematic networks: an analytic tool for qualitative research. Qualitative Research, 1(3), 385-405. https://doi.org/10.1177/146879410100100307

BAROK. (1999). Conflicts in the building and construction sector. Building and construction - Recruitment and competence development project.

Barriball, K. L., \& While, A. (1994). Collecting data using a semi-structured interview: a discussion paper. Journal of Advanced Nursing, 19, 328-335. https://doi.org/10.1111/j.1365-2648.1994.tb01088.x

Brockman, J. L. (2013). Interpersonal conflict in construction: cost, cause, and consequence. Journal of Construction Engineering and Management, 140(2). https://doi.org/10.1061/(ASCE)CO.1943-7862.0000805

Cakmak, E., \& Cakmak, P. I. (2014). An analysis of causes of disputes in the construction industry using analytical network process. Procedia - Social and Behavioral Sciences, 109, 183-187. https://doi.org/10.1016/j.sbspro.2013.12.441

Cheung, S. O., \& Pang, K. H. Y. (2013). Anatomy of construction disputes. Journal of Construction Engineering and Management, 139(1).

https://doi.org/10.1061/(ASCE)CO.1943-7862.0000532

Driscoll, D. L., Appiah-Yeboah, A., Salib, P., \& Rupert, D. J. (2007). Merging qualitative and quantitative data in mixed methods research: how to and why not. Ecological and Environmental Anthropology, 3(1), 18-28.

Elmagdobi, M. E., Čulić, N., Beljaković, D., Milajić, A., \& Pejičić, G. (2016). Common causes of conflicts in construction projects - comparative analysis of projects in Libya and Serbia. Archives for Technical Sciences, 8(1), 33-40. https://doi.org/10.7251/afts.2016.0815.033E

Engesæth, A. (2015). Increasing conflict level in the building and construction industry. Bergen: DLA PIPER.

Groven, V., Hafskjær, S., \& Ferstad, Ø. B. (2017). Disputes in construction projects. Trondheim: Norwegian University of Science and Technology.

Grøv, E. (2014). Norwegian contract practice suitable for dealing with unexpected geological conditions. In Norwegian tunneling technology (pp. 129-143). Trondheim: Norwegian Tunneling Society.

Gunnes, S. (2018). Disputes between contractor and owner: Owner withholding of payments. Oslo: Norwegian Association of Heavy Equipment Contractors (MEF).

Haukedalen, A. (2015). The conflict situation in the construction industry. NCC Construction AS.

Hegerberg, A. (2016). Cooperation between public clients and entrepreneurs on conflicts. Norwegian Public Roads Administration.

Henning, J. E. (2015). Selection of contractual forms and mechanisms for conflict management in the Norwegian Public Roads Administration. Norwegian Public Roads Administration.

Homleid, Å. (2016). Contractors meeting Solvik-Olsen Minister of Transport. Byggeindustrien, 18, 84.

Homleid, Å. (2015a, November). An intolerable conflict situation "En uholdbar konfliktsituasjon". Byggeindustrien.

Homleid, Å. (2015b, November). En uholdbar konfliktsituasjon. Byggeindustrien.

Jaffar, N., Tharim, A., \& Shuib, M. (2011). Factors of conflicts in construction industry: A literature review. Procedia Engineering, 20, 193-202. https://doi.org/10.1016/j.proeng.2011.11.156

Jahren, C. T., \& Dammeier, B. F. (1990). Investigation into construction disputes. Journal of Management in Engineering, 6(1). https://doi.org/10.1061/(ASCE)9742-597X(1990)6:1(39)

Kleivan, E. (1989). NOTCOS: The Norwegian tunneling contract system. Tunneling and Underground Space Technology, 4(1), 43-45. https://doi.org/10.1016/0886-7798(89)90031-X

Kobbe, H. S. (2016). Disagreements, conflicts and disputes: How to avoid and how to solve? Kluge Advokatfirma AS.

Kumaraswamy, M. M. (1997). Conflicts, claims and disputes in constrcution. Engineering, Construction and Architectural Management, 4(2), 95-111. https://doi.org/10.1108/eb021042

Lædre, O. (2015). Is there a case? Prevention and handling of disputes in construction and construction projects ( $2^{\text {nd }}$ ed.). Trondheim: Fagbokforlaget Vigmostad \& Bjørke AS.

Mehany, M. S., \& Grigg, N. (2014). Causes of road and bridge construction claims: Analysis of Colorado Department of Transportation Projects. Journal of Legal Affairs and Dispute Resolution in Engineering and Construction, 7(2), 04514006. https://doi.org/10.1061/(ASCE)LA.1943-4170.0000162 
Min, J. H., Jang, W., Han, S. H., \& Kim, D. (2018). How conflict occurs and what causes conflict: Conflict analysis framework for public infrastructure project. Journal of Management in Engineering, 34(4). https://doi.org/10.1061/(ASCE)ME.1943-5479.0000625

Mitkus, S., \& Mitkus, T. (2014). Causes of conflicts in a construction industry. Procedia - Social and Behavioral Sciences, 110, 777-786. https://doi.org/10.1016/j.sbspro.2013.12.922

Pavalon, E. I. (1987). ADR: Trial lawyer's perspective. Journal of Performance of Constructed Facilities, 1(4). https://doi.org/10.1061/(ASCE)0887-3828(1987)1:4(211)

Semple, C., Hartman, F. T., \& Jergeas, G. (1994). Constrcution claims and disputes: Causes and cost/time overruns. Journal of Construction Engineering and Management, 120(4). https://doi.org/10.1061/(ASCE)0733-9364(1994)120:4(785)

Tabish, S. Z. S., \& Jha, K. N. (2018). Beyond the iron triangle in public construction projects. Journal of Construction Engineering and Management, 144(8).

https://doi.org/10.1061/(ASCE)CO.1943-7862.0001517

The Construction Industry Institute. (1995). Dispute prevention and resolution techniques in the construction industry. Austin: The University of Texas at Austin.

Thompson, R. M., Vorster, M. C., \& Groton, J. P. (2001). Innovations to manage disputes: DRB and NEC. Journal of Management in Engineering, 16(5).

https://doi.org/10.1061/(ASCE)0742-597X(2000)16:5(51)

\section{APPENDIX}

\section{Notations}

\section{Abbreviations}

BAROK - Building, Construction, Recruitment and Competence Development report.

NPRA - Norwegian Public Roads Administration.

STATSbygg - The Norwegian Directorate of Public Construction and Property.

Norsk Hydro - Norwegian aluminum and renewable energy company.

Bane NOR - Norwegian National Rail Administration.

MEF - Norwegian Association of Heavy Equipment Contractors. 